\title{
WAR AS EXIT FROM EXCLUSION? THE FORMATION OF MAYI-MAYI MILITIAS IN EASTERN CONGO
}

\section{Koen Vlassenroot \& Frank Van Acker}

\section{Centre for Third World Studies}

University of Ghent

Universiteitstraat 8

B - 9000 Gent

\author{
e-mail: Koen.Vlassenroot@rug.ac.be
} acker-simons@hotmail.com

\section{SUMMARY}

War as Exit from Exclusion? The Formation of Mayi-Mayi Militias in Eastern Congo

In eastern Congo scores of young and marginalized people have been increasingly attracted to the mobilising efforts of new local actors. The inquiry into this phenomenon traces the emergence of the first militias to the end of the eighties. These first generation militias were a result of the growing willingness of marginalized youngsters and school drop-outs to form groups of under-aged combatants acting 
against every representative of modern political authority and against their desperate feelings of exclusion, for which both their political and social environment were held responsible. As they had nothing more to lose than their marginalization, rebellion became an option, both as a survival strategy and as a strategy of self-defence against a predatory political and social order. The shiftiness of their ideological basis and allies only further proved what these first militias were about: a search for alternatives to a situation of acute deprivation.

This article reveals that the present $R C D$ rebellion that rages through the eastern parts of the Democratic Republic of Congo has had an escalating effect on the proliferation of new militias. Before, the Kabila-led AFDL rebellion had already offered the already existing militias a new cause: that of an anti-Tutsi force fighting against foreign occupation. In resistance to the effects of state collapse and armed foreign interventions, rural and urban youth today have combined former traditions and newly developed patterns of mobility in an interpretation of customary and national defence. This has not meant that they link up with the traditional emanations of authority. Rather, a crisis in the social fabric has meant a shift in authority towards these combatants and the use of violence. In addition, shared feelings of antipathy towards the 'Tutsi-aggressors' have facilitated the creation of links between these diverse local groupings and other, foreign, factions of armed militia roaming the local countryside. Consolidation, however, remains unlikely as this shared ideology does not run very deep and alliances continuously change.

The question remains what the future impact of these militias might be on the local social order. On the one hand, for several years now in some remote areas these armed groupings have become the only representatives of any authority structure, even if this structure is based on violence. Contrary to other cases, these militias in South Kivu are still closely linked to the rural population and have not turned against them. On the other hand, the dynamic of the InterCongolese Dialogue has forced their leaders to present their grievances to the outside world. 
Key Words: Mayi Mayi, militias, politics, rebellion, R.D. Congo

\section{INTRODUCTION: A DIFFERENT DRUM}

The kind of conflict that currently haunts Eastern Congo challenges the traditional notion that violence ought to promote clearly defined political objectives. Today, journalists and academicians alike are strongly attracted to the premise that this violence is to be interpreted as the next demonstration of 'African Barbarism'.' Our research however, suggests the need for a different perspective in order to understand such violence as political. The role of dispossessed youth searching for ways to achieve a modicum of status in a much more fluid and unpredictable social landscape, has scarcely been highlighted. In addition, the scale of the grey and illegal markets (highvalue extractable resources, arms, and drugs) and the possibilities for their integration has vastly increased. Violence is used as a means to reorganise economic space and control mobility within and between spaces. War is then understood as an effort to concentrate violence in manageable and exchangeable forms. As Donald Crummey states: the real challenge is to see violence within its social setting, to appreciate its roots in social conflict, and to understand why and how people turn to $\mathrm{it}^{2}{ }^{2}$ Even those cases where rebel movements condone atrocities against their own communities (the LRA in Northern Uganda or the different militia in Liberia or Sierra Leone for example) should be understood as a manifestation of political violence. To a certain extent, violence is turned into an attack on society itself, because of a deep-rooted crisis of confidence in the principles of social accountability of state institutions. ${ }^{3}$ In this sense, terror - however

\footnotetext{
1 KAPLAN, R.D., The coming anarchy; how scarcity, crime, overpopulation, tribalism, and disease are rapidly destroying the social fabric of our planet, in: The Atlantic Monthly, February 1994.

2 CRUMMEY, D., Introduction: 'The Great Beast", in: CRUMMEY, D., (ed.), Banditry, Rebellion and Social Protest in Africa, London, Portsmouth, James Currey, Heinemann, 1996(2), p. 3.

${ }^{3}$ RICHARDS, P., "New Political Violence in Africa. Secular Sectarianism in Sierra Leone”, in: GeoJournal , 0, 1999, pp. 1-10.
} 
abject and cruel - is not so much random as exemplary, directed, and proportioned. The use of exemplary terror provides today an alternative option to gain access to power for those generations that suffered the effects of educational collapse and social exclusion. This stands in contrast to the seventies for example. The generations of young Zairians that grew up then, could and did look for meaningful social integration via the creation of alternative structures that later constituted the bulwark of civil society. But times are very different now. In Eastern Congo, the frustration caused by social exclusion is shared by a large number of young Congolese that show a growing willingness to act against what they perceive to be the root of the current crisis, i.e. the so-called Rwandan occupation of their province. In what follows we will give center stage to the role of marginalized youth in the ongoing conflict. More specifically, we'll focus on the genesis of youth militia - in casu the Mayi-Mayi - and the use of violence to power a fundamental change in the social structure. We will also pay attention to the fact that the boundaries of economic space are shifting as well, in such a way that the role of these militia is crucial in coupling local to regional and even wider dynamics. Before engaging these arguments, we need to briefly situate two stepping stones that will allow the reader to contextualize the analysis and see it in a historical framework.

First, the link between the organisation of space and social structure.

Social fragmentation in Kivu is the outcome of a long process that resulted in a different economic use of the available space and the mobility of labour within it. In Kivu as in other semi-feudal systems, the economic use of space expressed in the land tenure systems traditionally reflected the social organisation. The gradual reorganisation of that space by the entrance of new participants via politics and the market, especially after independence, eroded the customary social organisation. The result was a structural change of rural society, most notably a change in the nature of risk pooling at the community level (when viewed as a network of households) and at the household level itself. The market, rather than the patron-client relations inherent in the traditional social structure, increasingly mediated the handling 
of risks associated with subsistence living. The nature of these changes, in combination with population growth, produced an agricultural labour surplus of mostly young men.

Second, the link between violence and social stratification.

The principle of stratification under Mobutu -converting political loyalty into economic assets - required the regular recycling of the political elite, under his proverbial divide-and-rule strategy. As the crisis of the state became more pronounced, the available assets dwindled. Combining this aspect with the push for democratization in the nineties, Mobutu encouraged exit-strategies based on ethnic criteria. Local political leaders enforced the suggested exit of a particular group by mobilizing outsiders to that group. The loot would be based on 'self-service'. Destined to be a self-defeating strategy in the long run for Mobutu, it did introduce violence based on ethnic identity as a legitimate instrument to bring about change. More especially, it upgraded the status of those young men marginalized in the customary networks of dependency. The Rwandan refugee crisis and the subsequent wars further reinforced the view that violence based on ethnicity and carried out by groups of mobile youth had become the dominant principle to effect structural change.

On the basis of these two leads, we posit that the context of statedisintegration and growing insecurity gave rise to the development of new strategies of economic control. Disorder, insecurity and a general state of impunity encouraged the formation of new and militarised networks for the extraction of economic benefits. Reference to ethnic belonging became an integral and crucial part of both strategies of control and resistance. Three different but intertwined dynamics can be distinguished. First, at a grassroot level, the formation of militia offered opportunities to the younger generation to escape from further alienation. In the current context, violence actually helps them in their search for new forms of integration. Many young Congolese today reject the existing social and political order and opt for new egalitarian forms of social organisation. Violence as the main mode of discourse increases the influence of this generation of 'combatants'. Second, the shift to violence as a legitimate tool for social interaction gave rise to 
a new kind of local strongmen, in some cases former armycommanders. These try to control what remains of local market structures though militarised informal networks. These 'local warlords' find in the existing grassroot militia an easy power-base for the protection of their rent-seeking activities, which in turn gave a new impulse to militia-formation. Their attempts to coordinate the activities of the different branches of the Mayi-Mayi and link them to the remnants of Interahamwe $\mathrm{e}^{4}$ and $\mathrm{FDD}^{5}$ has added an extra dimension to the existing conflict. Third, warlordism is not only reduced to local actors, but seems to be one of the driving forces of some RPA- ${ }^{6}$ and UPDF- ${ }^{7}$ commanders actually present in Eastern Congo.

\section{THE FORMATION OF ENCLAVES: MAYI-MAYI AS STRATEGY OF EXIT OR ENTRY?}

Banned from any meaningful political participation, young Congolese in Eastern Congo opt for violence as a way to provide a semblance of social integration and access to some of the 'fruits of modernity'. Besides joining the rural militia, temporarily there was the alternative of enrolling in Kabila's rebel army as 'Kadogo' (small one). In Bukavu and Goma, hundreds of young people joined the Kabila-led $\mathrm{AFDL}^{8}$ rebel-movement after the defeat of the 'Forces Armées

\footnotetext{
${ }^{4}$ The interahamwe is a Rwandan militia and one of the executors of the genocide in Rwanda in 1994.

${ }^{5}$ The 'Front de la Défense de la Démocratie' is a Hutu-militia that has been instituted in the Burundian refugee-camps in eastern Congo. It acts against the Burundian Tutsiled regime and since 1998 became part of the Kabila-coalition.

${ }^{6}$ Rwanda Patriotic Army, the official Rwandan army.

${ }^{7}$ Ugandan People's Defence Forces, the Ugandan official army.

${ }^{8}$ Alliance des Forces Démocratiques pour la Libération du Congo/Zaïre, the rebelmovement that started its military campaign against Mobutu in October 1996 and was led by Laurent-Désiré Kabila.
} 
Zairoises' of the Mobutu-regime. Masasu's presence as one of the four leading members of the AFDL was a crucial element in this mobilisation campaign. Masasu, himself a young man from Bukavu, grew immensely popular with the young crowds as he provided proof of a new type of social mobility. The public meetings of the AFDL in Goma and Bukavu converted many youngsters from a public of eager listeners to active participants in what was presented as a liberation war. However, these young people commonly known as 'kadogo', were merely driven by opportunist motives rather than by a new patriotic spirit as. After all, they had never really known the state as anything of substance. As a survey demonstrates, $25 \%$ of the kadogo joined the AFDL-forces on the promise of generous compensation, a social position, and other material interests. ${ }^{9}$ Some $28 \%$ explained that the social situation at home and the lack of employment opportunities forced them to look for other options, while $15 \%$ said to have been convinced by other kadogo. Retribution against the ex-FAZ was cited as the main reason by $15 \%$ of the respondents. Only $7 \%$ claimed to have joined the AFDL because of a patriotic wish to liberate the country from Mobutu's shackles. The survey also revealed that most of the young people took their decision without consulting their parents. Only $20 \%$ of them became a soldier with the consent of their parents. In the field, given their lack of training, the kadogo turned out to be one of the weakest links in the army and consequently received hardly any battleground responsibility. The best they could hope for was to be trained as bodyguards of ranking commanders. Most kadogo considered Masasu as their only leader. Following his arrest in 1997, most of them were forced to regroup in training camps such as Kibomango near Kisangani, where they were almost completely excluded from any further military participation. ${ }^{10}$ Many left these camps and joined the ranks of the Mayi-Mayi, while others stayed to be integrated in the different rebel armies under Rwandan or Ugandan tutelage. Certainly, a sense of frustration with Kabila and a

\footnotetext{
${ }^{9}$ Unicef-survey, Bukavu, 1997.

${ }^{10}$ Actually, Masasu was arrested on the accusation of forming a private militia, while conducting a field-campaign to integrate the kadogo into the FAC.
} 
reaction against his action of imprisoning Masasu may have been elements in those choices. But staying in the army was still experienced as a better alternative than going back to their families. It might be worthwhile here to qualify the meaning of army as an ordered force. The ones present in the DR Congo are to a large extent made up of irregulars. As Onyango-Obbo noted in a column in the 'East African': most of the soldiers in all but two of the foreign armies are irregulars, drawn from the riff raff in the villages, petty thieves on the streets, demobilised soldiers, and militias. ${ }^{11}$

At this point, we need to explain the role and position of the MayiMayi as a particular expression of social integration and resistance. First, the development of organized forms of social resistance does not start from scratch, but implies a certain path-dependency. This we need to demonstrate. Second, we need to embed the origins of the current resurgence of Mayi-Mayi firmly within a dynamics of social exclusion. Third, we will argue that a movement like the Mayi-Mayi can be considered as a sort of 'enclave'.

We argue here that the newly formed militia in Eastern Congo should be interpreted as experiments with more egalitarian forms of social organisation for self-help and protection, with violence as the main mode of discourse. Obviously, bizarre patterns of dress, behaviour and violence are associated with the Mayi-Mayi. This aspect is associated with the use of spiritual products developed by their own spiritdoctors and diviners ('ganga-Mayi', mostly girls) to become invulnerable during military actions. It is their belief that bullets will turn into water. What is more relevant however, is the strict moral code that aims to create and enforce a form of egalitarianism between the different members of the militia. In this sense do the spiritual fetishes function as a token of membership and bond between the different individuals. From this vantage point, the movement can be considered as a sort of 'enclave'. By this we mean an egalitarian organisation that differentiates itself from the surrounding social structure by its internal organisation and egalitarian attachments, but

\footnotetext{
${ }^{11}$ Charles Onyango-Obbo, The East African, 13 December 1999.
} 
also - and more importantly - by its broad rejection of society as a whole $^{12}$. In fact this type of organisation should be seen as a reaction against the failing state institutions and is presented as an alternative to the existing patrimonial social order. In this way, the formation of Mayi-Mayi is a social process that - in the rejection of the going institutional order - creates a rationality of its own, especially when the existing environment offers opportunities to build and exploit clandestine trade networks and induces the development of warlord activities. The traditional authorities considered the Mayi-Mayi initially as an easy instrument to protect their position of control over land allocations. More ominously perhaps as an indication of their temperament, the movement also served the interests of local businessmen from the very start of its resurgence. It is generally accepted for example, that Nande-merchants mobilised the Bangilima (the local name for the Mayi-Mayi militia) in their competition with Tutsi-businessmen to protect their economic position in North Kivu. The same ambiguity can be found in the role - and exemplar - played by the Zairian army (FAZ). As early as 1986 the FAZ - like the Kasindiens (the militia that operated near the Ruwenzori Mountains) later - was very active around Beni, officially to prevent Congolese dissidents from infiltrating from neighbouring Uganda. In reality, local FAZ-officers created a climate of constant insecurity in order to protect their private rent-seeking activities such as the control over the export of coffee, gold and other minerals. Both the FAZ and the police forces were actively involved in the different orchestrations of interethnic violence. This allowed them to profit from the disorder for their businesses as well as gain financially by offering protection to the highest bidders.

All this leaves some questions as to the role and position of the MayiMayi for the future development of the conflict. Are they merely a modern interpretation of traditional brigands or benefactors that seek to rid Kivu from ethnic overlords? In order to clarify this issue, we have to consider in a bit more detail the context of the ongoing

12 DOUGLAS, M., In the Wilderness: the doctrine of defilement in the Book of Numbers, Sheffield, JSOT Press, 1993. 
conflict in the Kivu provinces, and how the history of the Mayi-Mayi relate to it.

\section{THE PROFILE OF THE MAYI-MAYI GROUPINGS}

Of course, it would be very misleading to suggest that all the MayiMayi groupings are part of one bigger movement. In order to give a better idea of the very broad range of motivations, objectives and social background of the different militias, a closer analysis is needed. Today, the Mayi-Mayi are covering a variety of groups that includes both well-defined and structured groups with a clear political agenda and loose gangs of social bandits, only using the name of Mayi-Mayi to cover their violent behaviour and abuse of the population. The best way to demonstrate the very strong differences between the different militias is to present their development from a historical approach.

Local resistance in Eastern Congo did not develop from scratch, given a strong foundation of traditional beliefs to build on. At different times in a not too distant past, local tribal militia mobilised the population to defend the traditional rural order against what were seen as foreign (colonial) influences. Examples are the Kitawala in North Kivu and the Binji Binji sect in South Kivu in 1931. The name Mayi-Mayi itself appeared for the first time during the sixties, when local militia among the Babembe in South Kivu allied themselves with the Mulelist rebellion against Mobutu's army. The main reason for their existence was to counter what they saw as an encroachment upon their tribal areas by Banyarwanda in the Fizi-Baraka area.

Besides of the historical examples, two generations of Mayi-Mayi militias can be distinguished: those groupings that started their activities before the 1996 AFDL-campaign and those that were formed as a consequence of the 1996 and 1998 rebellion. The origins of the first generation of Mayi-Mayi have to be located in a dynamics of social exclusion. 
ethnic groups

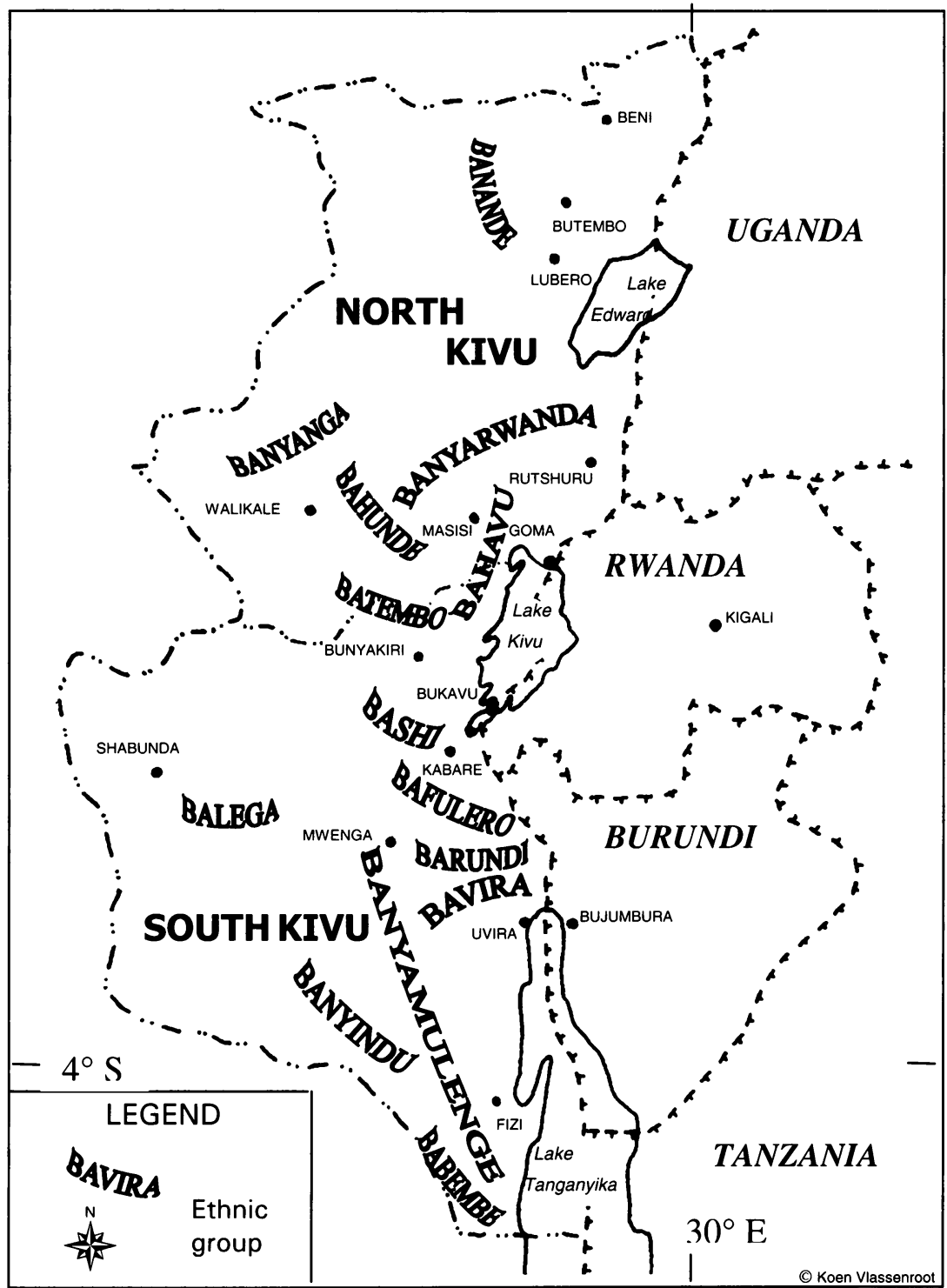


Not surprisingly therefore, the Mayi-Mayi resurfaced in the most marginalized communities. Already in the early nineties, local youth in Congo-Manday and Kasingi (North-Kivu) formed rural and crossborder gangs known as the Kasindiens. These targeted the existing political institutional order, including the power of the traditional chiefs which the Kasingiens considered to be 'prostitutes' of Mobutu. To conclude therefore that a degree of path-dependency, or historical continuity, in the local concept of violent resistance automatically translates into a bond between traditional authorities and the MayiMayi, would be erroneous. From the Kasingiens, the phenomenon of militia-formation spread to other regions of Eastern Congo. The Kasindiens soon started to co-operate with other militias: the Ngilima, based in Lubero and Beni (North-Kivu) drawing its members mainly from the Nande (as the Kasingiens did), the Katuku, operating in the southern parts of Walikale (North Kivu), and the Batiri, operating in Masisi (North-Kivu).

In North Kivu, a wave of interethnic violence erupted for the first time in March 1993. Prior to the conflict, poor Hutu farmers from Masisi that had lost their land because the local customary chiefs had sold it to rural capitalists of Banyarwanda-origin, had settled in Walikale, where they hoped to get access to land that was controlled by Nyangachiefs. Fearing a growing influence of these newly arrived HutuBanyarwanda, both the local population and their chiefs protested against their presence and supported the formation of local militias. After 1990, also a coalition of Nande and Hunde politicians, who were afraid to lose their political power if the Banyarwanda would be registered as Zairian nationals and participate in the coming elections, started an exclusion campaign to prevent the Banyarwanda from political participation. As a reaction, in the Rutshuru region the local Banyarwanda association Magrivi (Mutuelle des Agriculteurs de Virunga) had encouraged its members to refuse to pay tribute to the autochthonous chiefs and no longer recognise their authority. Also the Rwandan presidency fomented this conflict in order to cut the support lines between the local Tutsi population and the RPF. And finally, the indigenous customary authorities in Masisi felt their position threatened by the Banyarwanda communities and, within a context of intense political animosity, had no other option left than to start a 
campaign against these 'foreigners'. The best way to do so, was to mobilise the local youngsters that had already shown their preparedness to take up their machetes for the defence of their own community.

In March 1993, these militias killed several people at a local market in Ntoto. Although these attacks did not spread further into Walikale, Hunde-militias started attacking Banyarwanda in Masisi district for which they received some help from Nande-militias from Ruwenzori ${ }^{13}$ and from local FAZ-elements. The result was a bloody confrontation that lasted for more than six months and between 6000 and 10000 people were killed and more than 250.000 people displaced. At that time 'Mayi-Mayi/Bangilima' came to be used as a loose term for the description of any local armed youth group, suggesting somewhat prematurely a unification of all these local groupings. Since the first outbreak of massive violence in North-Kivu however, suggestion and reality have grown closer together, as these local militia have played a crucial role in the development of informal militarised social networks. Fighting became the best way to escape from marginalization because it had proved to offer these militia members with an easy access to livelihoods.

The fragile settlement between the different communities in North Kivu, which was eventually forged at the end of 1993 lasted till the arrival of more than one million Rwandan refugees and the settling of the ex-Far and Interahamwe in the different camps in Masisi and the Ruzizi Plains. The presence of the Rwandan refugees had some major effects on the local security situation yet at the same time these refugees created some new opportunities for the local grassroots militias. The position of the Mayi-Mayi during this refugee crisis was rather confusing, since their ideology proved to be a very flexible one and was mainly created in order to achieve what seemed rather shortterm parochial goals. Two different dynamics interacted. On the one

\footnotetext{
${ }^{13}$ It is said that soon after the arrival of the Nande-fighters in Masisi, serious problems arose between them and the local Hunde-fighters, who refused to follow the orders of these Nande-commanders. Finally, these Nande were forced to return to the Ruwenzori-mountains.
} 
hand, the violent acts of the Interahamwe not only were directed against the local Tutsi-population, but also against everyone that was not willing to support them, turning the existing rural militias into a necessary condition for survival. On the other hand, a generation split, which was the result of a growing gap between the 'haves' and the 'have-nots', pushed a growing number of marginalized young men into the direction of the same armed groupings.

The start of the AFDL-rebellion was the next turning point in the history of the Mayi-Mayi militias. First, in communities that previously had been untouched by the dynamic of militia-formation, rural militias started mushrooming. Especially in South Kivu, newly formed local militias became important components of the local political and military balance of power. According to some local observers, the Bembe in Fizi-Baraka had started to resist the AFDLrebel movement after one of their priests had been killed by Banyamulenge soldiers and given to their dogs. From then on, retreating FAZ elements were ordered to hand over their arms, which permitted the Bembe-militias to protect themselves against the AFDLtroops and to settle their old scores with the Banyamulenge. After some of their neighbours were appointed into key-positions within the new AFDL-administration, additional numbers of Bembe youngsters felt strongly attracted by the Mayi-Mayi. Even more important were local developments in Bunyakiri. Although since the Masisi conflict of 1993, local militias (known as Katuku) had been present in this region, it was only after the AFDL had taken Bukavu that these became significant players in the local power game. Initially, they formed a new alliance with Interahamwe and ex-FAR elements against the AFDL that was seen as a Tutsi movement. After some meetings with Kabila, part of them joined the AFDL-forces while others were kept in the forest in order to be able to protect the local population when needed. Those who stayed behind would become the backbone of one of the best-organised militias operating at present in eastern Congo.

In October 1996, retreating FAZ-elements on their way to Kisangani passed through Bunyakiri. Shortly after their arrival they were followed by fleeing Interahamwe militias, which rallied the local 
population against the Tutsi-led AFDL-movement. The result was a conjunction of local and regional actors and a massive mobilisation of local youngsters, which found its expression in an intensified formation of local militias. For the first time in their existence, these local armed groupings could get easy access to weapons, ammunition and the logistic help from FAZ- and Interahamwe-elements. Local spiritual doctors offered the fighters with the necessary protection and invisibility in battle. Also the local population put all its confidence in this alliance, which was considered as a patriotic force that was fighting against the 'Tutsi-led AFDL-rebels'.

From December 1996, however, some AFDL-leaders attempted to integrate the local fighters in their forces in order to continue their advance towards Kisangani. A delegation of both groups met just outside the Kahuzi-Biega Parc. After the Batembo-leaders had been convinced that the AFDL was a Congolese resistance movement that aimed at liberating the country, an agreement was signed about military co-operation. The AFDL was offered free passage to Kisangani (under the condition that only non-Tutsi fighters would pass trough Bunyakiri) and several thousand Mayi-Mayi fighters joined the ranks of the AFDL. Yet, not all Mayi-Mayi fighters had reinforced the AFDL. On the one hand, for the protection of their own community, the Batembo leaders had found it cautious to keep a large number of them staying behind. On the other hand, the local Interahamwe elements experienced this rapprochement as an act of betrayal of their Mayi-Mayi allies and retreated to the forest.

Those who had stayed behind moved their headquarters to Kambale and came to be headed by a certain Padiri. Padiri, who disputed the recruitment of thousands of Mayi-Mayi fighters by the AFDL-forces, invited the local traditional authorities and other local leaders and explained them that the agreement with the AFDL would only bring more trouble. From his headquarters, he started reorganising the remaining parts of the Mayi-Mayi and continued his battle against the Kabila-led coalition.

After the start of the RCD-rebellion, the local political and military landscape once again underwent a total reshuffle. The changing 
political environment also had a strong impact on the Mayi-Mayi militias because the new context of war and state implosion linked these grassroots realities directly to regional political dynamics in the shape of informal militarised networks. On the one hand, the nature of the current conflict has wrapped the movement with a fresh legitimacy in its struggle against the Rwandan dominance. In this light, the promotion by Kabila of some Mayi-Mayi commanders into key-positions of the Congolese army has to be explained as a tactical ploy to integrate these militias in his strategy to gain internal legitimacy, on the basis of an ultra-nationalist discourse. On the other hand, the state of disorder created the necessary conditions for the formation of new militias and, more importantly, for the spreading militarisation of informal social networks.

Contrary to the recent history of militia formation in the Kivus, however, from August 1998 the proliferation of militias was mainly limited to South Kivu. With the exception of a number of smaller Mayi-Mayi groupings between Beni and Butembo and in Walikale, from then on, the most important militias were to be found in South Kivu. In October 2001, the most influential militia-leaders or groupings in North and South Kivu were:

- General Padiri, who is leading the Bunyakiri group but is also controlling smaller militias and is without any doubt the most influential Mayi-Mayi leader;

- Dunia, the most influential militia-leader of the Bembe community;

- Madoa-Madoa and Kayumba, two other Bembe-leaders operating in Fizi-Baraka,

- Nakabaka and Zabuloni, former Simba-members and mainly operating around Uvira and the Ruzizi Plains

- and the Mudundu 40, the Bashi-militia from Walungu. 
As the local balance of power and the existing alliances drastically changed, the Mayi-Mayi leaderships were forced to find themselves a new political and military position. Due to the efforts of the former $F_{A C}{ }^{14}$-general Lwecha, who was also a former Simba and since the AFDL rebellion had become one of Kabila's closest allies, some of the Mayi-Mayi leaders were ready to reassess their relationship with Kinshasa. In return, the Kabila-government supplied them with arms, ammunition and instructors, and named some of the militia-leaders to top positions in the FAC. From September 1998, Lwecha also tried to co-ordinate his efforts with the Forces Armées de Libération contre Tutsi (FAL), which has its support base among the Batembo along the road between Kisangani and Bukavu, the Forces Armées Populaires (FAP) in Fizi-Baraka, and with Burundian and Rwandan Hutu militias. In doing so, Kinshasa tried to regain some legitimacy in the east and extend its military capacities. Although most Mayi-Mayi representatives stressed that this material support was hardly sufficient to continue their activities, for most observers it was proof that the different militias in the east had become an integral part of the official Congolese army. At least, this material support from Kinshasa has permitted the Mayi-Mayi militias to intensify its military activities and to shift its tactics from hit and run methods to long-term occupation of large tracts of land. Their resistance against what was locally perceived as a 'foreign occupation', meanwhile had resulted in growing popular support and gave them new symbolic backing.

Yet, the RCD-rebellion produced an additional effect. A context of growing impunity and authority crisis, gave a new dimension to the formation of local militias. While initially, the formation of local militias could be considered a form of bottom-up violence as a solution to social and economic marginalization or appeared to be rural based movements of self-defence, since August 1998 the distinction between some Mayi-Mayi chiefs and local warlords became rather fuzzy. In the present context of state implosion and conflict, the importance of the Mayi-Mayi expanded due to the attempts of a new class of local strongmen to unify the different

\footnotetext{
${ }^{14}$ Forces Armées Congolaises, the present official Congolese army.
} 
ethnically embedded, armed groups for the defence of their vested interests. The new tradition of violence and the very strong sentiments against the 'foreign occupation' of their province offered opportunities for new local strongmen. Militarised informal networks had to make possible the continuation of profit-seeking activities through the use of violence. The strongly pronounced anti-Tutsi ideology in most cases is only a convenient cover pretext for a broad range of local political and economic interests.

Not only local strongmen tried to mobilise these militias for their own profit. Also at grassroots level, excluded youngsters started forming violent bands, hoping to realise their materialistic dreams. A perfect illustration of this dynamic is the Bashi militia. Although in Ngueshe, the appearance of Mayi-Mayi can easily explained by the loss of political power and economic control of the local Bashi since 1996 and the destruction of the Royal Tombs by AFDL-elements, other, more down to earth reasons could be traced as well. Two sons of an uncle of the local mwami joined the Mayi-Mayi partly as a result of a local customary conflict between their father and the administrateur de territoire. Through the formation of a local branch of the MayiMayi, they hoped to regain control of the land (which is said to contain some gold). Once this militia was instituted, the local Mwami and the urban Bashi-elite that was closely associated with the civil society in Bukavu, started to support this militia and tried to restructure it. It was given a new name (Union des Forces pour la Libération du Congo or Mudundu 40), and Odilon Kurengamuzima, a nephew of the Mwami Ndatabaye, was chosen to be the military commander. Officially, this Bashi-militia was instituted as a reaction against the presence of Rwandan troops in South Kivu. In reality, it had to serve other objectives as well. The Mwami Ndatabaye tried to get this militia under his control in order to guarantee his authority within the Bashi community. For the civil society leaders, it was the perfect instrument to continue its campaign against the rebel forces and to politically reposition itself. Nevertheless, in 2000 this Bashi coalition fell apart into two groupings. Civil society leaders instituted the Parti de Resistance Nationale (PRN). The military wing renamed itself Forces de Résistance et de la Défense du Kivu (FRDK), and 
started talks with the RPA-forces in order to jointly attack the Interahamwe-elements that are still present in the Bushi territory.

\section{KOMONA CLAIR: TO BE WISE OR CUNNING?}

Based on this historical account, a number of arguments needs some specific attention. First, at different levels, war has evolved as an alternative way to gain profit, power, and protection. Warlordism itself is not limited to local actors, but includes many of the past (exFAZ, ex-FAC) and current (RPA, UPDF) commanders involved in the subsequent phases of the conflict in Kivu. Second, the enduring context of war and state implosion has created possibilities to link grassroot realities directly to regional political dynamics. The MayiMayi constitute the essence of that link in the shape of an informal militarized network. Third, the shiftiness of the Mayi-Mayi reflects the success of the alliances between the actors at the different levels, in harnessing the potential power of that informal fabric at grassroot level for their attempts to gain economic control.

The arrival of more than one million Rwandan and Burundian refugees created massive new opportunities to enforce the link between rent-seeking activities and the use of military force, as the reports of the UN International Commission of Inquiry on the trade of small arms revealed. By bringing together three elements - the different military actors and militia of the region (including the Interahamwe), the funds lifted from Rwanda's coffers by the engineers of the Rwandan genocide, and the logistic facilities provided by Mobutu - the refugee-camps provided ideal conditions for the unrestrained proliferation of weapons. The position of the MayiMayi in all this may seem rather confusing. In general, they legitimise their actions based on a strongly pronounced ethnic ideology. However, the content of this ideology does not prove to be a very stable one, as the Mayi-Mayi appear to form shifting alliances in order to achieve what seem rather short-term parochial goals. This explains why they joined the Kabila-led rebellion against Mobutu but opposed 
it when it came to power. The initial support for the AFDL could be explained as a continuation of their antecedent conflict with a coalition of local Hutu-combatants and Rwandan Interahamwe. The familiar explanation is that the Mayi-Mayi started to oppose Kabila when the AFDL turned into a Tutsi-led movement, foreshadowing a Rwandan occupation. To illustrate this, observers present the destruction of the 'royal tombs' in Kabare and the generalized looting after the RPA's second invasion, as one of the main motives for the formation of new groups of Mayi-Mayi. Without downgrading this argument, an alternative explanation underlines that the Mayi-Mayi movement shifted allies when Kabila refused to offer them compensation for their help in the military campaign against the Hutu refugees. On the contrary, as we stated earlier many of them ended up in camps such as Kapalata near Kisangani. These camps turned out to be mere prison colonies where many died of cholera and malnutrition. From 1997 onwards, most of the Mayi-Mayi groups joined forces with the roaming bands of defeated Interahamwe, ex-FAR, and Burundian FDD. A combined force of Mayi-Mayi, Interahamwe, and Ugandan ADF rebels for example, carried out attacks in Western Uganda to conquer Nyakahuka airstrip for an air-link and supply-route. ${ }^{15}$ This episode suggests a political consolidation of the movement, as well as a military strengthening. Nevertheless, the cloak of 'anti-Tutsism' can cover many things. The Mayi-Mayi continue to be a shifty force, constituting a flexible and attractive instrument of destabilisation in alliances with aspirant strongmen that often seem hard to fathom.

The current context of war and state implosion link grassroot realities directly to regional political dynamics in the shape of informal militarized networks. Emerging local strongmen - be they exMobutist, ex-FAC, or other - attempt to unify the different, often ethnically embedded, armed groups for the defence of their personal stakes. As early as 1997 there was a first serious attempt in SouthKivu to co-ordinate the activities of different Mayi-Mayi groups and urban political movements. Since the start of the second rebellion in August 1998, renewed attempts to unify all these groups have been

15 The New Vision, Rwandan, DRCongo rebels implicated in attacks in Western Uganda, Kampala, 18 December 1999. 
much more successful. On the one hand, the nature of the current conflict wraps the movement with a fresh legitimacy in its struggle against the Rwandan dominance. In this light, the promotion by Kabila of some Mayi-Mayi commanders as part of his ultra-nationalist discourse to gain internal legitimacy created a new dynamic and resulted in an increase of military activity. On the other hand, the actual state of disorder creates the necessary conditions for the formation of new militia and, more importantly, for the further militarization of informal social networks.

One of the most striking consequences of the $\mathrm{RCD}^{16}$-rebellion that started in 1998, is the increased militarization of society. Not only there is the formation and disintegration of new rebel-movements. The ongoing state of disorder also favours the development of militia, which are offering new opportunities for the younger generations. More important even is the tendency in the countryside of a shift of authority within each community to the advantage of a new class of warlords. Since 1998, Mayi-Mayi groupings no longer are only joined by young and marginalized peasants, but also by a class of bettereducated urban youth. In most cases, these new recruits are driven by personal economic motives rather than by patriotic or nationalistic sentiments. There is no doubt, however, that the actual strength of the Mayi-Mayi is closely related to attempts of the Kinshasa-government since the Lusaka Agreements to mobilise these militia in its attempts to open a second front in the Eastern provinces. Since August 1999, there is a strong growth in military capacities and activities of these grassroot militias in both North and South Kivu. The Mayi-Mayi leaders Dunia around Fizi and Baraka, Padiri around Bunyakiri, Shikatende in the Moyen Plateaux and Luecha in Shabunda and Mwenga regularly receive military support since their appointment as FAC Commanders in September 1999. But also the encouragement of Interahamwe and FDD-militia to create local militia in order to legitimize their existence, explains the increase in military strength of the Mayi-Mayi. Especially in South Kivu, many Mayi-Mayi groupings

\footnotetext{
${ }^{16}$ Rassemblement Congolais pour la Démocratie, the Rwandan supported rebel movement that started its military campaign against the Kabila-regime in August 1998.
} 
are now trained and controlled by Interahamwe or FDD-leaders. For the RCD, today the Mayi-Mayi pose a serious military threat. As a local RCD-Commander stated: ils sont maintenant capables de se présenter sur un front large et de mener des opérations militaires, ce qui est nouveau. A coalition of FDD, Interahamwe and Mayi-Mayi is controlling large parts of the countryside, while violence in South Kivu is also moving to the outskirts of Bukavu.

Since the end of 1999 , the security situation has mainly deteriorated in mining districts. As militia-leaders now control most of the economic activities in mineral-rich zones, the Mayi-Mayi groupings, as well as the Interahamwe and FDD are creating their own local war-economies and are getting economically stronger. Important with a view to the eventual resolution of the conflict in Congo, the actual state of disorder offers the conditions necessary for the formation of new patterns of economic control, and hence for the perpetuation of the conditions that sustain the conflict. At different levels, war is becoming a way of creating an alternative system of profit, power and protection. ${ }^{17}$ Even at the grassroot level, economic relations are highly militarised. There is of course the well-known and rather 'traditional' plundering by diverse military. Grossly underpaid - if paid at all - soldiers survive by looting, harassment, and robbery. Local commanders often orchestrate these episodes of looting, turning into small entrepreneurs themselves. In regions that are under control of the Mayi-Mayi, combatants force the local population to perform manual labor and to pay taxes at local markets. ${ }^{18}$ The development of warlordism as a strategy of economic control is giving new impulses to the dynamics of militia-formation. The shift to violence gave rise to a new kind of local strongmen (in most cases former armycommanders), that try to control the remaining local markets through militarised informal networks. These 'local warlords' find in the existing grassroot militia an easy power-base for the protection of their rent-seeking activities. Their attempts to coordinate the activities

\footnotetext{
${ }^{17}$ KEEN, D., The Economic Functions of Violence in Civil Wars, Adelphi Paper, no., $320,1997$.

${ }^{18}$ Author's interview, Bukavu, May 1999.
} 
of the different branches of the Mayi-Mayi and to link them to the remnants of Interahamwe and FDD have given another dimension to the existing conflict. Most notably, new local strongmen are developing strategies to gain control over the artisanal production of high-value goods. Since September 1998 for example, a former FACgeneral has been inciting ethnic strife while recruiting fighters among the Warega in the gold-rich regions of Kamituga and Mwenga (SouthKivu). In order to establish control over the local exploitation of gold around Kamituga and to modify existing trade patterns, he attempted to co-ordinate with the different Mayi-Mayi groups and Burundian and Rwandan Hutu-militia in the area. Another leader controls the Lulingu gold mines, while it is believed that a third Mayi-Mayi leader controls the existing trade-patterns of gold between Tanzania and South Kivu.

Warlordism, however, is not limited to local actors. It seems to be one of the driving forces of some RPA- and UPDF-commanders present in Eastern Congo. The most important level of rent-seeking activities enforced by the use of violence, is without any doubt that of the external forces involved in the DRC-conflict, as was confirmed by two recent UN-reports on the illegal exploitation of natural resources in the DR Congo. This 'external greed' is indicated by the extent of commercial activities in Eastern Congo developed by some RPA-and UPDF-commanders close to the political centres in Kigali and Kampala. This puts forward the question whether this practice of pillaging is a consequence of the actual state of disorder and conflict or, to the contrary, should be understood as functional for those controlling these illicit networks. Without proffering definite answers, there is solid ground to doubt whether security reasons were the sole motivation for the Rwandan and Ugandan support of the second rebellion. Even a strong military presence in the DRC could not manage to seal the borders between Congo and Uganda and Rwanda to insurgents. They could not prevent the killing of eight tourists in Bwindi in March 1999 or the reassembling of some 4000 Interahamwe as they moved from Walikale to Burundi. It would be more realistic to state that the intervention in Zaire since 1996 opened up important commercial opportunities and made it possible to extract extensive economic rents through the exploitation of local mines. Both Ugandan 
and Rwandan officers are actively involved in the exploitation of gold and other high-value goods such as colombite-tantalite (coltan). These activities were made possible by Kabila's initial attitude of laissezfaire. Examples are the creation of the company 'Caleb International' in Kisangani by Salim Saleh - Museveni's half-brother and general of the UPDF - in 1997, in view of getting a monopoly over the production of the Kilomoto goldfields. ${ }^{19}$ Once Kabila came to power however, he showed his determination to reduce the rent-seeking activities of his Eastern allies and get a better grip on local mining production himself. This of course heightened frictions between the former allies from the start of 1998 onwards. The support of the second so-called rebellion again suggests the primacy of economic interests over security reasons. Both on the Ugandan and Rwandan side, militaro-commercial lobbies profit from a context of insecurity to increase their control over the remaining economic fabric, often mobilising local businessmen in Goma, Bukavu or Kisangani, and linking up with international commercial partners. ${ }^{20}$ Activities are not limited to the exploitation of mines but include the control over the import of petrol and other more mundane products such as cigarettes. In the RPA-controlled areas, Rwandan agents have been assigned to all revenue-generating services. Military entrepreneurs take advantage of a climate of insecurity, but also cause further tension due to their differing individual interests, as evidenced by the frequent clashes between the RPA and the UPDF in Kisangani.

\footnotetext{
${ }^{19}$ In the fiscal year 1996-1997, Uganda earned over \$100m from the export of gold, adding it to the country's major foreign exchange earners. In comparison, the previous fiscal years of $94-95$ and $95-96$ yielded resp. $\$ 12.44 \mathrm{~m}$ and $\$ 35 \mathrm{~m}$. As an article in the New Vision reports on 24/05/97, the 'increase was attributed by an official of the bank to some gold leakages into Uganda from neighbouring Zaire'; Frank Van Acker, Beyond Berlin, NCOS mimeo, June 1998.

${ }^{20}$ The crash of a little Cessna plane of Tropical Airways in October 1998 in Beni raised some questions about the activities of some influential Ugandans in the DRC. One of the people that died during this crash was Jet Mwebaze of De Beers, who was involved in a gold deal in collaboration with Salim Saleh.
} 


\section{CONCLUSION: VIOLENCE AND THE SOCIAL ORDER}

Contrary to most observers, we have tried to understand the MayiMayi militias as an autonomous dynamic rather than as a local reaction against the presence of foreign troops. Categorising these militias in terms of their own self-description would have been as misleading as condemning the naked militia-fighters at the border-gate in Goma as a manifestation of social deviance, encouraged by their Rwandan or Tutsi-enemies. Rather than nominating the Mayi-Mayi fighters as a resistance movement driven by nationalistic ideals, we have tried to present their rebellion as a reaction against marginalization and exclusion and an option to despair. Even if today many youngsters feel attracted by the anti-Rwandan discourse of their leaders, this philosophy is not a cause of their existence but is facilitating the further proliferation of militias by offering it a very sexy ideological underpinning.

The question remains what, on the long term, will be the effects on their rebellion on the existing social order. Will the random MayiMayi fighter shift towards the Lord's Resistance Army ${ }^{21}$-type warrior that is turning violence into an attack upon society itself? If the acts of their Burundian comrades-in-arms are to be seen as a precursor of their own behaviour, then their recent abduction of an important number of children in order to train them as FDD-fighters can only lead us to some very grim prospects. So far, we do not believe that this will also happen in eastern Congo in the near future. Neither do we think that the Mayi-Mayi militias will progress towards a Revolutionary United Front-alike rebel-movement. The present MayiMayi militias, with the exception of the roaming bands of social bandits acting under the banner of Mayi-Mayi, are still very attached to the rural society in which they recruit their fighters and operate. Even more, most of their aims and objectives are concentrated on the protection and development of their own communities.

\footnotetext{
${ }^{21}$ This militia operates in Northern-Uganda and is characterised by its terror against the local population.
} 
This is not to say that the proliferation of militias in the Kivus is not producing any effects at all on the social order at all. The presence and actions of the Mayi-Mayi does have some severe effects on the existing rural order. First, the present conflict and proliferation of armed militias is realising a shift in authority to the advantage of those in charge of armed groupings. As we have illustrated, a fierce competition between a new generation of militia-leaders and the traditional authorities can be witnessed. This is not a new phenomenon, as it was already one of the guiding forces of some militia-members in the sixties to replace the traditional chiefs and become the new leaders of their own ethnic community. Today, however, some Mayi-Mayi leaders have been more successful and have replaced the traditional authorities and have become the true leaders of those regions under their control. This shift of control is not limited to the leadership of communities but is also affecting lower levels of authority such as the family-leadership. Second, the militias are providing the fighters with a renewed identity, defined by their position as Mayi-Mayi fighter. Initiation rituals transform them into a protected guard of their community, but at the same time are clearly cutting the link with their former social environment. After being initiated, they live in a totally new environment, characterised by a different order and authority structure than the society they are originating from. Even when the rural population is supporting the activities of the militias, its members become alienated from their own families. This brings us to the third impact on the rural social order. Because being a rebel at present is becoming a career option for many youngsters, the local economic order is seriously affected as well. Contrary to similar militias in other regions, however, Mayi-Mayi militias do not represent a revival of local patrimonial power, because the population increasingly becomes estranged from the militiamembers. As a recent UN-report on the exploitation of resources in D.R.Congo states: [the Mayi-Mayi militias] se battaient contre l'Armée patriotique rwandaise (ARP) et le RCD pour les empêcher d'avoir accès à des ressources telles que la colombo-tantalite, les diamants et l'or. Ils considèrent que les revenus tirés de l'exploitation de ces ressources sont l'unique raison d'être de la poursuite de 
l'occupation par les militaires rwandais. ${ }^{22}$ Meanwhile, they are exploiting part of the mining centres themselves. Besides of the local mining industry, these militias are also trying to control the informal trading networks that have been traditionally the basis of everyday life. For the exploitation of these networks, the social mobility of the population has to be restrained and put under their management.

The question remains, in which direction the present militias will develop. Today a first serious disaffection from their social background can be noticed. One of the sourest observations is that the Mayi-Mayi might eventually become a movement that is only directed at the survival of its own structures and, if necessary, will turn into an attack against the local rural society. Probably much will be depending on the position of the rural population, but also on the present dynamics of conflict. Also would it be very premature to see in these militias the potential of a new political force. As demonstrated, several constraints prevent the formation of a unified and centralised movement. Perhaps one would better not try to push the militia-leaders into the direction of the political game because the reward the young fighters would receive of their new leaders risks being very low, if any reward would be granted at all.

\footnotetext{
${ }^{22}$ UNITED NATIONS, Addendum to the Report of the Panel of Experts on the Illegal Exploitation of Natural Resources and Other Forms of Wealth of the Democratic Republic of the Congo, New York: UN Security Council, 10 November 2001, p. 26.
} 